\title{
WILEY
}

\section{American Finance Association}

Taxes and the Pricing of Stock Index Futures

Author(s): Bradford Cornell and Kenneth R. French

Source: The Journal of Finance, Vol. 38, No. 3 (Jun., 1983), pp. 675-694

Published by: Wiley for the American Finance Association

Stable URL: http://www.jstor.org/stable/2328076

Accessed: 12/09/2013 03:09

Your use of the JSTOR archive indicates your acceptance of the Terms \& Conditions of Use, available at http://www.jstor.org/page/info/about/policies/terms.jsp

JSTOR is a not-for-profit service that helps scholars, researchers, and students discover, use, and build upon a wide range of content in a trusted digital archive. We use information technology and tools to increase productivity and facilitate new forms of scholarship. For more information about JSTOR, please contact support@jstor.org. 


\title{
Taxes and the Pricing of Stock Index Futures
}

\author{
BRADFORD CORNELL and KENNETH R. FRENCH*
}

\begin{abstract}
Stock index futures prices are generally below the level predicted by simple arbitrage models. This paper suggests that the discrepancy between the actual and predicted prices is caused by taxes. Capital gains and losses are not taxed until they are realized. As Constantinides demonstrates in a recent paper, this gives stockholders a valuable timing option. If the stock price drops, the investor can pass part of the loss on to the government by selling the stock. On the other hand, if the stock price rises, the investor can postpone the tax by not realizing the gain. Since this option is not available to stock index futures traders, the futures prices will be lower than standard no-tax models predict.
\end{abstract}

ON 24 February 1982, the Kansas City Board of Trade began trading futures contracts on the Value Line Average stock index. During the next two months, both the Chicago Mercantile Exchange and the New York Futures Exchange also initiated trading in stock index futures. Although these contracts are actively traded, their prices have puzzled both practitioners and academics. The observed price structure, which gives the relation between the futures and spot prices as a function of the time to maturity, is much flatter than simple arbitrage models predict. In fact, the futures prices are often below the spot price. For example, on 1 June 1982, the spot price for the S\&P 500 index was 111.68 and the December 1982 futures price was 110.55 .

In this paper, we suggest a solution to this puzzle that is based on Constantinides's [2] model of capital market equilibrium with personal taxes. The standard futures pricing models ignore an important difference between the way stock and futures contracts are taxed; futures traders in a cash settlement contract must pay taxes on all gains in the year they occur, while stockholders pay taxes only on realized gains and losses. This means that stockholders have a valuable timing option. If the stock price drops, the investor can pass part of the loss on to the government by selling the stock. On the other hand, if the stock price rises, the investor can postpone the tax by not realizing the gain. Since this option is not available to futures traders, the futures prices will be lower than the standard no-tax model predicts. In fact, this timing option can lead to the inverted price structures observed for stock index futures contracts.

Throughout the paper we assume that forward and futures prices are equal. Of course, it is now well known that these prices will not be exactly equal if interest

* Graduate School of Management. UCLA, Los Angeles. This research was supported by the Center for the Study of Futures Markets, Columbia University, and the Foundation for Research in Economics and Education, UCLA. We would like to thank Gordon Alexander, Fischer Black, Michael Brennan, Tom Copeland, Robert Geske, Dave Mayers, Richard Roll, Mark Rubinstein, Clifford Smith, Hans Stoll, and, particularly, George Constantinides for helpful comments. 
rates are stochastic. Cox, Ingersoll, and Ross [5], Jarrow and Oldfield [10], Richard and Sundaresan [14], and French [8] examine the theoretical difference between forward and futures prices in a variety of contexts. Nonetheless, simulations and empirical studies by Rendleman and Carabini [13], Cornell and Reinganum [4], and Elton, Gruber, and Rentzler [6] indicate that the difference is economically insignificant. ${ }^{1}$ In the remainder of the paper forward and futures prices are used interchangeably.

The empirical results presented in this paper are limited to contracts on the S\&P 500 index and the New York Stock Exchange composite index. The Value Line index is excluded because it is not a value-weighted average. Instead, it is based on a geometric average of the component stocks' price changes. This means that the rate of change in the Value Line index is not equal to the return one would receive from holding the component stocks. Rather than complicate the results of our study by attempting to adjust for the bias produced by the geometric averaging, we ignore the Value Line Contract.

In the next section, we derive the forward price for a stock or portfolio of stocks assuming that markets are perfect and that both the dividend payout and the interest rate are constant. The prices predicted by this model are significantly higher than the prices observed for stock index futures contracts. In Section II we extend the model by introducing stochastic interest rates, seasonally varying dividends, and a simple tax structure that does not include the timing option. Although this richer theory does lead to more accurate predictions, the theoretical prices are still consistently higher than the actual prices. Section III completes the model by explicitly recognizing Constantinides's timing option. Some very preliminary results support this model.

One popular explanation for the "low" level of futures prices involves the constraint traders face when selling stocks short; since these constraints are not imposed on futures traders, investors who want to go short may be attracted to the futures market and drive down the futures prices. This hypothesis is examined in Section IV. We find that short sale constraints alone will not lower the futures prices; however, these constraints play an important role when the timing option is introduced.

In the last section we discuss some implications of our model and summarize the paper.

\section{The Perfect Markets Model}

In this section we develop a model of stock index futures contracts under the following simplifying assumptions:

(1) Capital markets are perfect; there are no taxes or transactions costs, there are no restrictions on short sales, and assets are perfectly divisible;

(2) The riskfree borrowing and lending rates are equal and constant; and

(3) Dividends are paid continuously at a constant rate of $D$ dollars per period. Suppose a trader purchases one share of stock (or a portfolio of stocks) at time

\footnotetext{
${ }^{1}$ French [9] finds a statistically significant difference between futures and forward prices for copper and silver. However, since he finds that the futures prices are larger than the forward prices, distinguishing between these prices would magnify the puzzle, rather than explain it.
} 
$t$ for a price of $P(t)$ and then follows a trading strategy of investing all dividends in riskfree bonds. Since the dividends are paid continuously, the value of the portfolio at time $T$ is

$$
\begin{aligned}
V_{1}(T) & =P(T)+D \int_{t}^{T} e^{r(T-w)} d w \\
& =P(T)+(D / r)\left[e^{r(T-t)}-1\right]
\end{aligned}
$$

where $r$ is the continuously compounded interest rate. In other words, by investing $P(t)$ in the stock at time $t$, the trader can obtain $P(T)+(D / r)\left[e^{r(T-t)}-1\right]$ at time $T$.

An investor can also obtain this payoff by combining forward contracts and riskfree bonds at time $t$. Suppose the trader initiates one long forward contract with a price of $F(t, T)$ and invests $\left\{F(t, T)+(D / r)\left[e^{r(T-t)}-1\right]\right\} e^{-r(T-t)}$ in discount bonds. Since the forward contract has no value when it is written, the initial value of this portfolio is

$$
V_{2}(t)=\left\{F(t, T)+(D / r)\left[e^{r(T-t)}-1\right]\right\} e^{-r(T-t)}
$$

When the contracts mature at time $T$, the bonds yield $F(t, T)+$ $(D / r)\left[e^{r(T-t)}-1\right]$ and the forward contract yields $P(T)-\vec{F}(t, T)$. The total value of the portfolio is

$$
V_{2}(T)=P(T)+(D / r)\left[e^{r(T-t)}-1\right]
$$

This is exactly equal to the payoff received from investing $P(t)$ in the first portfolio strategy.

Since these two portfolio strategies have the same value at time $T$ (and since they do not involve any intermediate cash inflows or outflows) they must have the same value at time $t$. In other words, the stock price must equal

$$
P(t)=\left\{F(t, T)+(D / r)\left[e^{r(T-t)}-1\right]\right\} e^{-r(T-t)}
$$

Equivalently, the forward price must equal

$$
F(t, T)=P(t) e^{r(T-t)}-(D / r)\left[e^{r(T-t)}-1\right]
$$

The two terms in Equation (5) reflect two different factors. The first term arises because payment in a forward transaction is deferred until the contract matures. For example, consider a stock that does not pay any dividends. Holding a forward contract on this stock is exactly equivalent to holding the stock, except the stock requires payment at time $t$ while the forward contract requires payment at time $T$. Therefore, the forward price for a non-dividend-paying stock is equal to the deferred value of the stock price.

$$
F(t, T)=P(t) e^{r(T-t)}
$$

The second term in Equation (5) reflects the fact that forward traders do not receive dividends that are paid on the underlying security. Thus, the forward price is reduced by the time $T$ value on the dividends that are paid over the life of the contract.

Under the perfect markets assumptions, all of the variables that affect the 
forward price are directly observable. In fact, if the stock's dividend yield is defined as the dividend flow per dollar invested in the stock at time $t$,

$$
d=D / P(t)
$$

the forward price can be expressed as a function of only the stock price, the dividend yield, the interest rate, and the time to maturity,

$$
F(t, T)=P(t)\left\{e^{r(T-t)}[1-d / r]+d / r\right\}
$$

Table I compares the price structure implied by this model with prices observed in the futures markets on the first trading days of June, July, August, and September 1982. The theoretical prices are calculated using the interest rate on the Treasury bill that matures closest to the maturity of the futures contract. The annual dividend yield is assumed to be $6 \%$. Since the relevant dividend yields for both the New York Stock Exchange Composite index contracts and the Standard and Poor's 500 stock index contracts were in the range of $5 \%$ to $6 \%$ during the sample period, this assumption causes a slight downward bias in the theoretical prices. ${ }^{2}$

All but two of the predicted prices are higher than the actual prices. In fact, several of the observed price structures are inverted, with the futures prices below the spot price. Under the perfect markets model, this inversion will only occur if the dividend yield is larger than the interest rate. Equation (8) can be rewritten as

$$
F(t, T) / P(t)=1+\left[e^{r(T-t)}-1\right][1-d / r]
$$

Because $\left[e^{r(T-t)}-1\right]$ is positive, the futures-spot price ratio will be less than one if and only if $[1-d / r]$ is negative or, equivalently, if $d$ is larger than $r$. During the sample period, the Treasury bill rate was always greater than the dividend yield on the underlying portfolios, so the observed prices are inconsistent with the perfect markets model.

\section{Relaxing the Perfect Markets Assumptions}

The perfect markets model developed in Section I is based on several simplifying assumptions. In this section, we extend the model by introducing stochastic interest rates, fluctuating dividends, and a simple set of taxes. After examining the theoretical effects of these factors, we compare the predictions of the extended model with the prices observed in the futures market.

\footnotetext{
${ }^{2}$ The dividend yield for the S\&P 500 in the first week of May 1982 was $5.9 \%$. This yield is computed by Standard and Poor's as the value-weighted average of four times the latest dividend on each stock divided by the stock price on the declaration date. The dividend yield for the NYSE index, $5.1 \%$, is measured by the difference between the value-weighted return, including dividends, and the value-weighted return, excluding dividends, for New York Stock Exchange Stocks during 1981. These monthly returns are provided by the Center for Research in Security Prices at the University of Chicago.
} 
Table I

Actual Versus Theoretical Prices ${ }^{a}$

\begin{tabular}{cccc}
\hline & & & Perfect \\
Contract & Days to & Actual & Markets \\
Month & Maturity & Prices & Prices \\
\hline
\end{tabular}

1 June 1982: S\&P 500

Spot

$\begin{array}{rrr} & 111.68 & \\ 18 & 110.05 & 112.13 \\ 108 & 110.10 & 113.99 \\ 199 & 110.55 & 116.19 \\ 290 & 111.00 & 118.49\end{array}$

March 83

1 June 1982: NYSE

Spot

64.37

June

28

63.35

120

63.45

September

211

64.05

March 83

304

64.55

64.75

65.91

67.26

68.69

1 July 1982: S\&P 500

Spot

September

December

March 83

June

68

108.71

$77 \quad 109.85$

110.25

259

110.65

350

111.20

110.61

113.05

115.77

118.48

1 July 1982: NYSE

Spot

September

December

March 83

June

90

62.51

181

63.20

63.80

63.45

65.20

63.75

363

64.05

66.79

68.35

2 August 1982: S\&P 500

Spot

September

December

March 83

June

45

108.98

136

110.00

110.75

109.40

234

111.35

110.99

318

111.90

113.22

115.33

2 August 1982: NYSE

Spot

September

December

March 83

June

58

62.49

149

63.20

62.88

240

63.65

63.84

331

64.10

65.02

66.39

1 September 1982: S\&P 500

Spot

118.25

September

117.00

118.42

December

15

117.30

119.32

March 83

118.10

121.33

June

197

118.80

123.29 
Table I Continued

\begin{tabular}{lccc}
$\begin{array}{c}\text { Contract } \\
\text { Month }\end{array}$ & $\begin{array}{c}\text { Days to } \\
\text { Maturity }\end{array}$ & $\begin{array}{l}\text { Actual } \\
\text { Prices }\end{array}$ & $\begin{array}{c}\text { Perfect } \\
\text { Markets } \\
\text { Prices }\end{array}$ \\
\hline & 1 September 1982: NYSE \\
Spot & & 67.90 & \\
September & 28 & 67.25 & 68.07 \\
December & 119 & 67.45 & 68.62 \\
March 83 & 210 & 67.85 & 69.77 \\
June & 301 & 68.25 & 71.13 \\
\hline
\end{tabular}

${ }^{a}$ The prices predicted by the perfect markets model are based on the assumption that there are no taxes and that both the interest rate and the dividend yield are constant;

$$
F(t, T)=P(t)\left\{e^{r(T-t)}[1-d / r]+d / r\right\}
$$

The dividend yield is assumed to be $6 \%$ per year. The interest rate is measured by the rate on the Treasury bill that matures closest to the maturity of the futures contract.

\section{A. Stochastic Interest Rates}

The forward price in Section I deviates from the spot price because the forward payment does not occur until the contract matures and because forward traders do not receive the dividends paid on the underlying security. When a variable interest rate is added to the model, the forward price still equals the deferred value of the spot price minus the deferred value of the dividend payments, but now the interest rates used to cumulate the payments depend on when they occur. For example, the relevant return for determining the deferred value of the spot price is equal to the return on a discount bond that matures when the forward contract does, $r(t, T)$. The dividend payments in turn, are cumulated at the appropriate forward interest rate. Defining $R(t, w, T)$ as the forward rate at time $t$ for a loan that will be made at time $w$ and that will mature at time $T$, the forward price should equal

$$
F(t, T)=P(t) e^{r(t, T)(T-t)}-D \int_{t}^{T} e^{R(t, w, T)(T-w)} d w
$$

Since both the long term interest rate and the forward rates are observable at time $t$, this model applies whether the term structure moves deterministically or stochastically.

\section{B. Fluctuating Dividends}

Besides assuming that the interest rate is constant, the model of forward prices in Section I also assumes that the dividend flow from the underlying security or portfolio is constant. This assumption is not very accurate for individual stocks since most firms only pay dividends four times each year. Collecting stocks into portfolios reduces this lumpiness. However, even large portfolios exhibit seasonal fluctuations in their dividend flow since many firms issue their quarterly dividends at about the same time. Table II shows the monthly dividend yields, in 
Table II

1981 Monthly Dividend Yields for the NYSE Composite Index ${ }^{a}$

\begin{tabular}{cccccc}
\hline January & February & March & April & May & June \\
\hline $2.24 \%$ & $8.39 \%$ & $3.83 \%$ & $2.31 \%$ & $8.15 \%$ & $3.87 \%$ \\
July & August & September & October & November & December \\
\hline $2.24 \%$ & $8.90 \%$ & $3.72 \%$ & $4.15 \%$ & $8.68 \%$ & $3.63 \%$ \\
\hline
\end{tabular}

${ }^{a}$ The dividend yields are measured by the difference between the monthly value-weighted return, including dividends, and the value-weighted return, excluding dividends, for New York Stock Exchange Stocks. These monthly indexes are provided by the Center for Research in Security Prices at the University of Chicago. The yields have been converted to annual estimates by multiplying the monthly estimates by 12 .

annualized terms, for the New York Stock Exchange composite index during 1981. The dividend yields for February, May, August, and November are much larger than the yields for the other months. This seasonal variation in the dividend flow may have a significant effect on the observed prices. For example, compare two one-month futures contracts written on 1 April and 1 May. The effective annual dividend yields for these contracts are $2.31 \%$ and $8.15 \%$, respectively. A model that assumes that the dividend yield is constant over the full year will underprice the one-month April contract and overprice the one-month May contract.

As long as the dividend payout function for the underlying security is known when the contract is initiated, it is easy to modify the forward pricing models of Equation (5) and (10) to include varying payouts. The cumulated value of the dividends lost by holding the forward contract instead of the stock is equal to the sum of the time $T$ values of the dividends that will be paid at each instant. Therefore, the forward pricing model becomes

$$
F(t, T)=P(t) e^{r(t, T)(T-t)}-\int_{t}^{T} D(w) e^{R(t, w, T)(T-w)} d w
$$

where $D(w)$ is the instantaneous dividend payout at time $w .^{3}$

\section{The Effect of Taxes}

To examine the effect of taxes we assume that there are three relevant tax rates:

(1) Capital gains and losses are taxed at the capital gains rate, g; no distinction is made between short-term and long-term capital gains;

${ }^{3}$ If the dividend flow is not known at time $t$, the arbitrage argument in Section I breaks down and we must introduce an equilibrium model to determine the forward price. For example, suppose the dividend flow is stochastic, but independent of the market return. If we assume that the capital asset pricing model holds, the forward price is equal to

$$
F(t, T)=P(t) e^{r(t, T)(T-t)}-\int_{t}^{T} E[D(w)] e^{R(t, w, T)(T-w)} d w
$$

where $E[D(w)]$ is the expected dividend flow conditional on all the information available at time $t$. 
(2) Interest and dividend payments are taxed at the ordinary income rate, $i$; and

(3) Profits and losses from futures and forward trading are taxed at the futures rate, $f .^{4}$

For simplicity, we assume that the taxes on interest and dividends are paid continuously as the cash flows are received. Futures and forward profits are taxed when the contracts mature at time $T$. Taxes on both realized and unrealized capital gains are also paid at time $T$.

These assumptions allow us to replicate a long position in the stock with forward contracts and discount bonds, as we did in Section I. Suppose a trader purchases a share of stock at time $t$ and simultaneously enters into a series of forward bond contracts to invest the future dividends. Since these forward contracts do not require any initial investment, the cost of creating this portfolio is $P(t)$. The after-tax value at time $T$ is

$$
\begin{aligned}
V_{1}(T) & =P(T)-[P(T)-P(t)] g+\int_{t}^{T}(1-i) D(w) e^{(1-i) R(t, w, T)(T-w)} d w \\
& =P(T)(1-g)+P(t) g+\int_{t}^{T}(1-i) D(w) e^{(1-i) R(t, w, T)(T-w)} d w
\end{aligned}
$$

Alternatively, the trader could enter into $(1-g) /(1-f)$ forward contracts and invest

$$
\begin{aligned}
V_{2}(t)=[(1-g) & F(t, T)+P(t) g \\
& \left.+\int_{t}^{T}(1-i) D(w) e^{(1-i) R(t, w, T)(T-w)} d w\right] \times e^{-(1-i) r(t, T)(T-t)}
\end{aligned}
$$

dollars in riskfree bonds. At time $T$, the after-tax value of this portfolio is

$$
\begin{aligned}
V_{2}(T)= & \frac{1-g}{1-f}(1-f)[P(T)-F(t, T)]+(1-g) F(t, T)+g P(t) \\
& +\int_{t}^{T}(1-i) D(w) e^{(1-i) R(t, w, T)(T-w)} d w \\
= & P(T)(1-g)+P(t) g+\int_{t}^{T}(1-i) D(w) e^{(1-i) R(t, w, T)(T-w)} d w
\end{aligned}
$$

${ }^{4}$ The current tax code requires that all futures contracts must be "marked to the market" at yearend for tax purposes. This means that gains and losses on outstanding positions are computed and taxes levied just as if the positions had been liquidated. There is no distinction between short-term and long-term holding periods for futures. Forty percent of all gains are taxed at the long-term rate and sixty percent are taxed at the short-term rate. Capital gains taxes can be deferred on some futures contracts that mature before the end of the tax year by taking delivery of the commodity. However, this alternative is not available with stock index futures because they are cash settlement contracts. It should be added that there is some confusion about how the tax rules will be applied to stock index futures, because of legal technicalities related to this cash settlement feature. 
Again, these two portfolios have no intermediate cashflows and they have the same after-tax value at time $T$. To avoid dominance, the values at time $t$ must also be equal,

$$
\begin{aligned}
P(t)=[(1-g) F( & (t, T)+P(t) g \\
& \left.+\int_{t}^{T}(1-i) D(w) e^{(1-i) R(t, w, T)(T-w)} d w\right] \times e^{-(1-i) r(t, T)(T-t)}
\end{aligned}
$$

Rewriting Equation (15), the forward price must equal

$$
\begin{aligned}
F(t, T)=\left\{P(t)\left[e^{(1-i) r(t, T)(T-t)}-g\right]\right. & \\
& \left.-\int_{t}^{T}(1-i) D(w) e^{(1-i) R(t, \omega, T)(T-w)} d w\right\} / 1-g
\end{aligned}
$$

The forward price is a function of both the ordinary income tax rate, $i$, and the capital gains rate, $g$. However, it is not affected by the forward tax rate. To see the intuition behind this independence, recall that a forward contract can be viewed as a bet about the maturity spot price. ${ }^{5}$ Without taxes, the winning trader receives the difference between the maturity spot price and the forward price, $P(T)-F(t, T)$. If forward profits and losses are taxed, the payoff is reduced to $(1-f)[P(T)-F(t, T)]$. However, since no investment is required to initiate a forward contract, a trader can replicate a tax-free contract by entering into $1 /(1-f)$ taxable contracts. In effect, forward taxes change the size of the contract, but they do not change the equilibrium price. ${ }^{6}$

The ordinary income tax rate, $i$, does affect the forward price because it reduces both the effective dividend yield and the effective interest rate. These two reductions are partially offsetting; cutting the dividend yield raises the forward price, while reducing the interest rate lowers the forward price. However, if the interest rate is above the dividend yield, the interest rate effect dominates the dividend yield effect; ceteris paribus, an increase in the ordinary income tax rate will lower the forward price.

The effect of the capital gains tax is more complicated. Using Equation (16), the ratio of the forward price and the stock price can be written as

$$
\begin{aligned}
F(t, T) / P(t)=\left[e^{(1-i) r(t, T)(T-t)}-g\right. & \\
& \left.-\int_{t}^{T}(1-i) d(w) e^{(1-i) R(t, w, T)(T-w)} d w\right] /(1-g)
\end{aligned}
$$

${ }^{5}$ This does not imply that the forward price should be an unbiased predictor of the maturity spot price. See French [8] for a discussion of this point.

${ }^{6}$ Cox, Ingersoll, and Ross [5] also demonstrate that the futures price is not affected by taxes on futures profits. As they recognize, this independence does not hold unless we assume that profits and losses are taxed symmetrically. The assumption is a good approximation for cash settlement contracts, such as stock index futures. For deliverable contracts the symmetry breaks down because taxes on profits from long positions can be deferred by taking delivery. 
In this expression, the dividend yield at time $w$ is equal to the dividend flow per dollar invested in the stock at time $t$,

$$
d(w)=D(w) / P(t)
$$

The partial derivative of the relative forward price with respect to the capital gains rate is equal to

$$
\frac{\partial[F(t, T) / P(t)]}{\partial g}=[F(t, T)-P(t)] /[P(t)(1-g)]
$$

Since $[P(t)(1-g)]$ is always positive, the effect of the capital gains tax depends on the relative values of the forward and spot prices. Consider a trader who purchases one share of stock at time $t$. If the forward price satisfies Equation (16), the trader can recreate his stock position by initiating $(1-g) /(1-f)$ forward contracts and investing $P(t)$ in riskless bonds. The after-tax payoff from these forward contracts is $(1-g)[P(T)-F(t, T)]$. The trader has effectively changed the forward tax rate, $f$, to the capital gains rate, g. However, the tax basis for this position is still $F(t, T)$, while the basis for the stock is $P(t)$. Because of this difference, changing the capital gains rate changes the relative forward price. For example, if the forward price is above the stock price, an increase in the capital gains rate increases the tax liability of the stock more than it increases the tax liability of the equivalent forward portfolio. This increases the attractiveness of the forward portfolio relative to the stock. Therefore, if the forward price is above the stock price, the ratio of these prices must be an increasing function of the capital gains rate. On the other hand, if the forward price is below the stock price, capital gains taxes decrease the relative forward price. ${ }^{7}$

${ }^{7}$ If the dividend yield and the interest rate are constant, the combined effect of the ordinary and capital gains taxes is determined by the relative values of $d$ and $r$. Under the current tax code, the capital gains rate is effectively $40 \%$ of the ordinary income tax rate, $g=.4 i$. Using this relation, Equation (17) can be written as

$$
F(t, T) / P(t)=\left\{e^{(1-\imath) r(T-t)}[1-d / r]+d / r-.4 i\right\} /(1-.4 i)
$$

The partial derivative of this ratio with respect to the tax rate, $i$, is

$$
\frac{\partial[F(t, T) / P(t)]}{\partial i}=\left\{-r(T-t) e^{(1-i) r(T-t)}[1-d / r]+.4[F(t, T) / P(t)-1]\right\} /(1-.4 i)
$$

This partial derivative equals zero when $d$ equals $r$. Moreover, it is an increasing function of the dividend yield;

$$
\begin{aligned}
\frac{\partial[F(t, T) / P(t)]}{\partial i \partial d}= & \left\{r(T-t) e^{(1-i) r(T-t)}-[.4 /(1-.4 i)]\left[e^{(1-i) r(T-t)}-1\right]\right\} /[r(1-.4 i)] \\
= & \left\{(1-.4 i) r(T-t) e^{(1-i) r(T-t)}-.4(1-i) r(T-t)[1+(1-i) r(T-t) / 2 !\right. \\
& \left.\left.+(1-i)^{2} r^{2}(T-t)^{2} / 3 !+(1-i)^{3} r^{3}(T-t)^{3} / 4 !+\cdots\right]\right\} /\left[r(1-.4 i)^{2}\right] \\
> & \left\{(1-.4 i) r(T-t) e^{(1-i) r(T-t)}-.4(1-i) r(T-t)[1+(1-i) r(T-t)\right. \\
& \left.\left.+(1-i)^{2} r^{2}(T-t)^{2} / 2 !+(1-i)^{3} r^{3}(T-t)^{3} / 3 !+\cdots\right]\right\} /\left[r(1-.4 i)^{2}\right] \\
= & {[(1-.4 i)-.4(1-i)](T-t) e^{(1-\imath) r(T-t)} /(1-.4 i)^{2} } \\
> & 0
\end{aligned}
$$


Table III compares the prices predicted by Equation (16) with the prices observed for the NYSE composite contract and the S\&P 500 contract on the first trading day of June, July, August, and September. The predicted prices are based on very rough estimates of the relevant parameters. To obtain estimates of the daily dividend yield, we assume that the yield is constant within each calendar month and that it is equal to the yield for the value-weighted portfolio of NYSE stocks during the corresponding month of 1981. For example, the daily dividend yield during January is $0.006 \%(2.24 \% / 365)$.

The estimates of the relevant interest rates and forward rates are based on Treasury bill returns. Since these tests are very preliminary, and since we use monthly estimates of the dividend yields, we only use Treasury bills that mature on or around the first of each month. For example, the interest rate for contracts that mature between 16 September and 15 October is measured by the return on the 30 September Treasury bill. The forward rates are also constructed from these monthly rates.

Finally, we use two extreme assumptions about the marginal tax rates. In computing the first set of predicted prices, we assume that all tax rates are zero. The second set of predictions reflects an ordinary tax rate, $i$, of $50 \%$ and a capital gains rate, $g$, of $20 \%$.

The results in Table III indicate that the pricing model described by Equation (16) does not explain the observed futures prices; the theoretical prices are almost always higher than the actual prices. The predictions of the no-tax model are particularly inaccurate. For example, although the 1 June price for the December S\&P 500 contract is only 110.55 , the theoretical price for this contract is 116.42 . Adding taxes to the model does reduce the theoretical prices. However, even this richer model leads to predicted prices that are generally higher than the actual prices.

\section{The Timing Option and Future Prices}

In the previous section we assumed that both realized and unrealized capital gains are taxed. Although this assumption is standard in much of the finance literature, it is unrealistic because capital gains taxes are not levied until a transaction occurs. As Constantinides [2] demonstrates, this means that stockholders have a valuable timing option; they can reduce their taxes by realizing capital losses and deferring capital gains. Investors who hold stock index futures contracts do not have this timing option; all capital gains and losses must be realized either at the end of the year or at the maturity of the futures contract, whichever comes first. The arbitrage argument in Section II ignores this difference between stock and futures contracts. A trader who is long in the stock receives not only the cashflows from the "equivalent" forward portfolio, but also the opportunity to defer any capital gains taxes. Therefore, the stock price must be higher than the model in Section II predicts or, equivalently, the relative futures price must be lower.

Therefore, if the dividend yield is greater than the interest rate, the relative forward price is an increasing function of the marginal tax rate. If $d$ is less than $r$, the relative forward priced is a decreasing function of the tax rate. 
Table III

Actual Versus Theoretical Prices ${ }^{a}$

\begin{tabular}{ccccc} 
& & Theoretical & Theoretical \\
Contract & Days to & Actual & Prices & Prices \\
Month & Maturity & Prices & Without Taxes & With Taxes \\
\hline
\end{tabular}

Spot

June

September

December

March 83

Spot

June

September

December

March 83

Spot

September

December

March 83

June

Spot

September

December

March 83

June

Spot

September

December

March 83

June

Spot

September

December

March 83

June

Spot

September

December

March 83

June

Spot

September

December

March 83

June

1 June, 1982: S\&P 500

111.68

110.05

112.10

111.94

18

110.10

114.22

113.24

199

290

110.55

116.42

114.58

111.00

118.95

116.11

1 June 1982: NYSE

$\begin{array}{lll}64.37 & & \\ 63.35 & 64.74 & 64.61 \\ 63.45 & 66.01 & 65.39 \\ 64.05 & 67.29 & 66.17 \\ 64.55 & 68.79 & 67.05\end{array}$

1 July 1982: S\&P 500

108.71

109.85

110.25

110.65

111.20

110.51

109.86

168

259

350

112.93

111.31

115.65

112.94

118.36

114.56

1 July 1982: NYSE

$\begin{array}{lll}62.51 & & \\ 63.20 & 63.75 & 63.28 \\ 63.45 & 65.17 & 64.14 \\ 63.75 & 66.72 & 65.09 \\ 64.05 & 68.29 & 66.01\end{array}$

2 August 1982: S\&P 500 108.98

$\begin{array}{lll}110.00 & 109.18 & 109.10 \\ 110.75 & 110.88 & 110.16 \\ 111.35 & 113.08 & 111.51 \\ 111.90 & 115.19 & 112.78\end{array}$

2 August 1982: NYSE

$\begin{array}{lll}62.49 & & \\ 63.20 & 62.71 & 62.63 \\ 63.65 & 63.73 & 63.26 \\ 64.10 & 64.91 & 63.98 \\ 64.55 & 66.22 & 64.78\end{array}$

1 September 1982: S\&P 500

$\begin{array}{rrrr} & 118.25 & & \\ 15 & 117.00 & 118.37 & 118.32 \\ 106 & 117.30 & 119.42 & 118.98 \\ 197 & 118.10 & 121.44 & 120.22 \\ 288 & 118.80 & 123.77 & 121.64\end{array}$

1 September 1982: NYSE

a The theoretical prices are estimated by

$$
67.90
$$

67.25

67.45

67.85

68.25

\begin{tabular}{ll}
68.03 & 67.98 \\
68.69 & 68.40 \\
69.88 & 69.13 \\
71.23 & 69.94 \\
\hline
\end{tabular}

67.98

69.40

69.94

63.26

64.78

$F(t, T)=\left\{P(t)\left[e^{(1-i) r(t, T)(T-t)}-g\right]-\int_{t}^{T}(1-i) D(w) e^{(1-i) R(t, w, T)(T-w)} d w\right\} /(1-g)$ 
In analyzing the effect of the timing option on our model of futures prices, we shall continue to assume that taxes on interest payments and dividends are paid continuously, while profits and losses from futures trading are taxed when the contracts mature at time $T$. Taxes on realized capital gains and losses are also paid at time $T .^{8}$

Since capital gains and losses are taxed, the value of a share of stock depends on both the current price and the purchase, or basis, price. Let $Q[P(T), P(t)]$ denote the share value at time $T$ if the current price is $P(T)$ and the basis price is $P(t)$. This share value satisfies the following conditions:

$$
\begin{aligned}
Q[P(T), P(t)] & =(1-g) P(T)+g P(t) & & \text { if } P(T) \leq P(t) \\
& >(1-g) P(T)+g P(t) & & \text { if } P(T)>P(t)
\end{aligned}
$$

If the stock price falls from time $t$ to time $T$, the investor sells the stock and realizes his capital loss. Since he receives $P(T)$ directly from the sale and $g[P(t)$ - $P(T)]$ from the government, the total value of the stock is $(1-g) P(T)+$ $g P(t)$. The investor could also choose to sell the stock if the price rises from time $t$ to time $T$. Again, the value of the stock would be $(1-g) P(T)+g P(t)$. However, in this case the investor would be paying capital gains taxes, instead of receiving a tax refund. The stock is actually worth more than $(1-g) P(T)+g P(t)$ because the investor can continue to hold the stock and defer the capital gains taxes. ${ }^{9}$

To understand the impact of the timing option on the pricing of stock index futures, it is helpful to view a long position in the stock as a portfolio of two assets. The first asset generates the cashflows a trader would receive if he bought the stock at time $t$ and sold it at time $T$. The forced liquidation of this restricted security produces a tax treatment that is similar to the tax treatment for a futures contract. Although the tax rates are different, all of the capital gains and losses generated by both the restricted security and the futures contract are taxed at time $T$. The value of this restricted security at time $T$ is

$$
S(T)=P(T)-[P(T)-P(t)] g
$$

The second asset that combines to form the actual stock is an option to defer capital gains taxes. If the stock price falls from time $t$ to time $T$, this option is not valuable because there are no taxes to defer. Instead, both the stockholder and the owner of the restricted security receive a tax refund. However, if the

\footnotetext{
${ }^{8}$ We also simplify the discussion by implicitly assuming that stockholders wait until the end of the tax year (time $T$ ) to realize any capital losses. As Constantinides [2] demonstrates, this strategy is not optimal. If there are no transaction costs, it is better to realize capital losses as they occur. For example, suppose the stock price starts at $P(t)$, falls to $P(w)<P(t)$, and then goes back to $P(T)=$ $P(t)$. An investor who realizes capital losses as they occur could claim a tax refund of $[P(t)-P(w)] g$ and defer the concomitant capital gains tax; a stockholder who waits until time $T$ to realize capital losses will not generate a refund. The assumption that capital losses are not realized continuously simplifies the presentation without changing the qualitative results. Footnote 10 describes how the analysis is affected when this assumption is relaxed.

${ }^{9}$ Constantinides [2] derives an explicit solution for the valuation function, $Q[P(T), P(t)]$, under the assumption that capital gains taxes and refunds are paid and received continuously.
} 
stock price rises, the timing option becomes valuable; the stock is worth more than the restricted security. The owner of the restricted security pays taxes on the capital gains that are realized when it is sold, while the owner of the complete stock has a call option that can be used to offset these taxes. The value of the timing option is equal to the difference between the value of the stock and the value of the restricted security,

$$
C(T)=Q[P(T), P(t)]-S(T)
$$

Using Equations (20) and (21), this can be rewritten as ${ }^{10}$

$$
C(T)=\operatorname{Max}\{0, Q[P(T), P(t)]-(1-g) P(T)-g P(t)\}
$$

Although this partioning of a share of stock into a restricted security and a timing option appears to be artificial, it is exactly the way a futures contract partitions the stock. Since all futures are marked to the market at year end, a futures trader does not have the option to defer capital gains taxes. Therefore, the relevant asset for pricing the contract is the restricted security. In fact, the payoff on the restricted security is equal to the payoff on the stock that was used to derive the futures price in Section II. We can use an argument that is analogous to the one in Section II to show that the futures price should equal

$$
\begin{aligned}
F(t, T)=S(t)\left[e^{(1-i) r(t, T)(T-t)}\right. & -g \\
& \left.-\int_{t}^{T}(1-i) d(w) e^{(1-i) R(t, w, T)(T-w)} d w\right] / 1-g
\end{aligned}
$$

when the stock includes a timing option. This is equivalent to the model in Section II except the price of the restricted security has replaced the price of the stock. ${ }^{11}$

By construction, a portfolio of the timing option and the restricted security has the same value at time $T$ as a share of stock that was purchased at time $t$. Therefore, the portfolio must also have the same value as the stock at time $t$,

$$
P(t)=S(t)+C(t)
$$

${ }^{10}$ We have been assuming that stockholders wait until time $T$ to realize capital losses. Even if tax refunds are not received until that time, it is optimal to realize the losses whenever they occur. (See Footnote 8.) If this continuous realization is permitted, the payoff on the timing option increases to

$$
C(T)=\operatorname{Max}\{0,[P(T)-\operatorname{Min} P(w)] g-[P(T)-Q[P(T), \operatorname{Min} P(w)]]\} \text { for } t \leq w \leq T
$$

${ }^{11}$ To be exact, the dividend yield in Equation (24) should be redefined as

$$
d(w)=D(w) / S(t)
$$

When computing the estimates of the timing option values that are presented in Table IV, we use the dividend yield defined in Section II. However, we have recomputed these estimates with the adjusted dividend yield, and the results are nearly identical. 
This result can be used to rewrite Equation (24) as

$$
\begin{aligned}
F(t, T)=[P(t) & -C(t)]\left[e^{(1-i) r(t, T)(T-t)}-g\right. \\
& \left.-\int_{t}^{T}(1-i) d(w) e^{(1-i) R(t, w, T)(T-w)} d w\right] /(1-g) \\
= & {[1-c(t)]\left\{P ( t ) \left[e^{(1-i) r(t, T)(T-t)}-g\right.\right.} \\
& \left.\left.-\int_{t}^{T}(1-i) d(w) e^{(1-i) R(t, w, T)(T-w)} d w\right] /(1-g)\right\}
\end{aligned}
$$

where $c(t)$ is defined as

$$
c(t)=C(t) / P(t)
$$

Notice that the expression in brackets is equal to the futures price in Section II. In other words, the pricing model in Section II overstates the futures price by the relative value of the timing option.

Several factors will affect the value of the timing option. ${ }^{12}$ For example, Constantinides [2] demonstrates that the option value is an increasing function of the variance of the stock return. The intuition behind this conclusion is straightforward. If the expected rate of return is held constant, an increase in the variance increases the probability of both large positive and large negative stock price changes. However, this symmetry does not carry over to the option payoffs; large price increases generate large positive payoffs, while large price decreases do not generate large negative payoffs. Therefore, the expected payoff and the option value increase with the variance of the stock return.

Intuitively, it seems that the option value should also be an increasing function of the maturity of the restricted security. It is clear that the deferred value of the timing option grows with the time to maturity. This effect is very similar to the effect of an increase in the variance; the uncertainty about the maturity stock price increases with the time to maturity. An increase in the maturity has a second, compounding, effect if the expected change in the stock price is positive. The timing option is valuable when the stock price at time $T$ exceeds the basis established at time $t$. If the stock price has a positive drift, an increase in the time to maturity increases the expected maturity stock price and the expected payoff.

The effect of a change in maturity on the current value of the timing option is more difficult to determine. We know that the timing option is worthless if the restricted security matures immediately after it is initiated. We also know that

\footnotetext{
${ }^{12}$ We have been unable to find a general analytical valuation for the timing option. However, in personal correspondence, George Constantinides has demonstrated that the option can be valued under a specific set of assumptions. Using the binomial model developed in his recent paper entitled "Optimal Stock Trading with Personal Taxes: Implications for Prices and the Abnormal January Returns," he shows that the basis effect of the capital gains tax exactly offsets the option effect if the stock does not pay dividends.
} 
the option's value is positive when it is associated with a longer-lived security. However, without solving the differential equation for the price of the option we can not prove that the option value increases over all maturities. Since the differential equation has no known closed-form solution, our intuition about the relation between the value of the option and the maturity of the restricted security remains a conjecture. Of course, a numerical solution could be computed, but that is beyond the scope of this paper.

Finally, the value of the timing option is a decreasing function of the dividend yield. If the expected rate of return is held constant, a lower payout ratio makes it more likely that the stock price will rise. This, in turn, increases the expected payoff at time $T .^{13}$

Table IV presents some preliminary empirical estimates of the value of the timing option for several futures contracts. These estimates are obtained by comparing the observed futures prices with the prices predicted in Section II. Rewriting Equation (26),

$$
\begin{aligned}
c(t)=1-F(t, T) /\left\{P ( t ) \left[e^{(1-i) r(t, T)(T-t)}-g\right.\right. \\
\left.\left.-\int_{t}^{T}(1-i) d(w) e^{(1-i) R(t, w, T)(T-w)} d w\right] /(1-g)\right\}
\end{aligned}
$$

the relative value of the timing option is equal to 1 minus the ratio of the actual futures price and the futures price predicted by the model in Section II.

The option values in Table IV are based on the same rough parameter estimates that we used in the previous section. We assume that the tax rate on ordinary income is $50 \%$ and that the capital gains rate is $20 \%$. Each month's daily dividend yield is estimated by the average daily yield for the value-weighted portfolio of NYSE stocks during the corresponding month of 1981. The interest rates and forward rates are based on Treasury bill returns.

Although the results in Table IV are only designed to offer a rough check of our predictions, they are generally consistent with the model. As the model predicts, nearly all of the estimated values are positive; only five of the 32 estimates are negative. The results also support the proposition that the relative value increases with the maturity. For example, the June 1 estimates for S\&P 500 contracts with $1,4,7$, and 10 months to maturity are $1.7 \%, 2.8 \%, 3.5 \%$, and $4.0 \%$, respectively.

There is one puzzling aspect of the results in Table IV; the estimates of the relative value of the timing option fluctuate noticeably from month to month. This variation in the reported value of the option may be caused by two types of measurement error. First, the indexes are measured with error. Since the index values are based on the last price observed for each of the component stocks, new information will not be fully reflected in the indexes until a new price is observed for each of the stocks. This delay should not be observed in the futures

\footnotetext{
${ }^{13}$ Constantinides [2] finds that the value of his timing option increases with the dividend yield. This is consistent with our result because Constantinides defines the timing option as the right to receive tax refunds on capital losses, while we define it as the right to defer capital gains taxes.
} 
Table IV

Relative Value of the Timing Option ${ }^{\mathrm{a}}$

\begin{tabular}{|c|c|c|c|c|}
\hline \multirow[b]{2}{*}{$\begin{array}{l}\text { Contract } \\
\text { Maturity }\end{array}$} & \multicolumn{2}{|c|}{ S\&P 500} & \multicolumn{2}{|c|}{ NYSE } \\
\hline & $\begin{array}{l}\text { Days to } \\
\text { Maturity }\end{array}$ & $\begin{array}{l}\text { Relative Value } \\
\text { of Option }\end{array}$ & $\begin{array}{l}\text { Days to } \\
\text { Maturity }\end{array}$ & $\begin{array}{c}\text { Relative Value } \\
\text { of Option }\end{array}$ \\
\hline & & 1 June 1982 & & \\
\hline June & 18 & $1.69 \%$ & 28 & $1.95 \%$ \\
\hline September & 108 & $2.77 \%$ & 120 & $2.97 \%$ \\
\hline December & 199 & $3.52 \%$ & 211 & $3.20 \%$ \\
\hline \multirow[t]{2}{*}{ March 83} & 290 & $4.00 \%$ & 304 & $3.73 \%$ \\
\hline & & 1 July 1982 & & \\
\hline September & 77 & $0.01 \%$ & 90 & $0.13 \%$ \\
\hline December & 168 & $0.95 \%$ & 181 & $0.83 \%$ \\
\hline March 83 & 259 & $2.03 \%$ & 272 & $2.06 \%$ \\
\hline \multirow[t]{2}{*}{ June } & 350 & $2.93 \%$ & 363 & $2.97 \%$ \\
\hline & & 2 August 1982 & & \\
\hline September & 45 & $-0.82 \%$ & 58 & $-0.91 \%$ \\
\hline December & 136 & $-0.54 \%$ & 149 & $-0.62 \%$ \\
\hline March 83 & 227 & $0.14 \%$ & 240 & $-0.19 \%$ \\
\hline \multirow[t]{2}{*}{ June } & 318 & $0.72 \%$ & 331 & $0.36 \%$ \\
\hline & & 1 September 1982 & & \\
\hline September & 15 & $1.12 \%$ & 28 & $1.07 \%$ \\
\hline December & 106 & $1.41 \%$ & 119 & $1.39 \%$ \\
\hline March 83 & 197 & $1.76 \%$ & 210 & $1.85 \%$ \\
\hline June & 288 & $2.33 \%$ & 301 & $2.42 \%$ \\
\hline
\end{tabular}

a The relative value of the timing option is expressed as a percentage of the stock price. It is estimated as

$c(t)$

$$
\begin{gathered}
=1-F(t, T) /\left\{P ( t ) \left[e^{(1-i) r(t, T)(T-t)}-g\right.\right. \\
\left.\left.-\int_{t}^{T}(1-i) d(w) e^{(1-i) R(t, w, T)(T-w)} d w\right] /(1-g)\right\}
\end{gathered}
$$

market; the expected impact of new information will be reflected immediately in the futures prices. The second measurement error arises because the stock market closes at 4:00 P.M. (EST) and the futures market closes at 4:15. Since our estimates are based on closing prices, this difference can cause spurious movement in the observed option values. ${ }^{14}$

Under this measurement error hypothesis, our estimates of the option value

${ }^{14}$ For example, the Federal Reserve Board announces the money supply figures at 4:10 P.M. on Friday afternoon. Cornell [3] and Roley and Pearce [12] find that the new information contained in these announcements has a highly significant impact on stock prices. This information will be reflected in the futures price on Friday afternoon, but will not affect cash prices until the opening of the market on Monday morning. 
are positively biased when bad news is announced late in the day and negatively biased when good news is announced. This hypothesis appears to explain the negative option values for 2 August. For example, the reported change in the December futures price is +2.9 points, while the reported change in the S\&P 500 index is only +1.9 points. Moreover, a check of the option values for 3 August indicates that they are all positive.

\section{The Role of Short Sale Constraints}

In developing the perfect markets model in Section I, we assumed that there are no short sale constraints. Although this assumption is accurate for the futures market, it is not true in the stock market. Traders do not have full use of the proceeds when they sell stocks short. It may seem that this difference alone is sufficient to cause the relatively low prices observed for stock index futures; investors who want to go short will be attracted to the futures market and will drive down the futures prices. If we continue to assume that there are no transaction costs, this argument is not convincing. It overlooks the fact that long traders can also move from the stock market to the futures market. If the futures price dropped below the level given by Equation (26), stockholders would sell their shares and replace them with futures contracts and bonds; the price would fall and the futures price would rise until Equation (26) was satisfied. ${ }^{15}$

The introduction of transaction costs weakens this counterargument; movement between the stock and futures markets only guarantees that the futures price will be "close" to the price predicted by Equation (26). However, the allowable deviations are smaller than they might appear. Substitution of futures contracts for stock does not necessarily involve sale of the stock. For example, if the futures price is below that predicted by Equation (26), an investor entering the market may initiate futures contracts rather than buy stock. ${ }^{16}$

Even without transaction costs, short sale constraints play an important role when stockholders have the option to defer capital gains taxes. Consider a portfolio of identical long and short positions in the same security. ${ }^{17}$ When taxes are levied on all capital gains and losses, the value of this portfolio is identically zero. However, if only realized gains and losses are taxed, both the short and the long positions provide valuable timing options. Any change in the stock price allows the trader to realize a loss and obtain a tax refund. For example, if the stock price falls the investor liquidates his long position, receives a tax refund, and immediately repurchases the stock. Since this portfolio generates only positive cash flows, its initial value must also be positive-the price of the stock

\footnotetext{
${ }^{15}$ Another explanation for the low futures prices was suggested by Michael Brennan. Currently, corporations are allowed to exclude $85 \%$ of their dividend income. If corporations are the marginal investors in common stock, the effective tax rate on dividends, relative to interest income, is lower than we assume. This means that the ratio of the futures price to the stock price will be smaller than our model predicts.

${ }^{16}$ Figlewski [7] and Modest and Sundaresan [11] discuss these issues in greater detail.

${ }^{17}$ Investors with identical short and long positions are subject to special tax rules. To avoid this complication, we assume that the long and short securities are distinct for tax purposes, but that their returns are perfectly correlated.
} 
must be higher than the proceeds from the short sale. In other words, short sale constraints are necessary to prevent arbitrage.

Short sale constraints in the stock market also prevent arbitrage in the futures market. Suppose a trader forms a portfolio involving a short position in the stock and a long futures position. If the trader has full use of the proceeds from the short sale, this portfolio could be used to generate arbitrage profits for two reasons. First, the short stock position provides an option to defer capital gains taxes. Second, the price of the futures contract is not based on the full stock price, but only on the price of the restricted security. As before, the short sale constraints must offset the combined effect of timing options from both long and short stock positions.

\section{Summary and Conclusions}

This paper examines the pricing of stock index futures contracts. Under the standard assumption that taxes are levied on both realized and unrealized capital gains, we find that the futures price will differ from the stock price for two reasons. First, payment for the stock is required today while the futures payment is deferred until the contract matures. Second, the futures trader does not receive the dividends that are paid to the stockholder. Although we incorporate seasonal dividends and a variable term structure of interest rates, this model consistently overpredicts the observed futures prices.

However, this standard model fails to take account of the timing option available to owners of common stock. Because taxes are not levied until a transaction occurs, a stockholder has the option to realize losses and postpone gains. This option is not available in the futures markets; all capital gains and losses must be realized either at the end of the year or at the maturity of the contract, whichever comes first. Including the tax option in our model reduces the predicted futures prices.

The results have an important implication for tax-exempt investors. If the marginal investor were tax-exempt, then the timing option would be worthless and the "perfect markets" pricing model should work. In fact, the observed futures prices are significantly below the predictions of the perfect markets model. This means that tax-exempt investors who wish to hold a diversified portfolio of common stocks could increase their return, without bearing greater risk, by purchasing bonds and futures contracts rather than buying the stock. Given the structure of futures prices it appears that tax-exempt investors are not yet active investors in the futures market. It will be interesting to see if the price structure changes as institutions enter the market in larger numbers.

\section{REFERENCES}

1. G. M. Constantinides. "Optimal Stock Trading with Personal Taxes: Implications for Prices and the Abnormal January Returns." Unpublished working paper, Center for Research in Security Prices, Graduate School of Business, University of Chicago, 1982.

2. _- "Capital Market Equilibrium with Personal Tax." Econometrica, forthcoming, 1983.

3. B. Cornell. "Money Supply Announcements and Asset Prices: Review and Interpretation." 
Unpublished working paper, Graduate School of management, UCLA, 1982.

4. - and M. R. Reinganum. "Forward and Futures Prices: Evidence From the Foreign Exchange Markets." Journal of Finance 36 (1981), 1035-45.

5. J. C. Cox, J. E. Ingersoll, and S. A. Ross. "The Relation Between Forward and Futures Prices." Journal of Financial Economics 9 (1981), 321-46.

6. E. Elton, M. Gruber, and J. Rentzler. "Intra-day Tests of the Efficiency of the Treasury Bill Futures Market." Unpublished working paper, New York University, 1982.

7. S. Figlewski. "Stock Index Futures: Theory and Application in a New Market." Unpublished working paper, Graduate School of Business, University of California, Berkeley, 1982.

8. K. R. French. "The Pricing of Futures and Forward Contracts." Unpublished Ph.D. dissertation, University of Rochester, 1982.

9. - "A Comparison of Futures and Forward Prices." Unpublished working paper, Graduate School of Management, UCLA, 1982.

10. R. A Jarrow and G. S. Oldfield. "Forward Contracts and.Futures Contracts." Journal of Financial Economics 9 (1981), 373-82.

11. D. M. Modest and M. Sundaresan. "The Relationship Between Spot and Futures Prices in Stock Index Futures Markets: Some Preliminary Evidence." Journal of Futures Markets, forthcoming, 1983.

12. D. P. Pearce and V. V. Roley. "The Reaction of Stock Prices to Unanticipated Changes in Money." Unpublished working paper, Federal Reserve Bank of Kansas City, 1982.

13. R. J. Rendleman and C. E. Carabini. "The Efficiency of the Treasury Bill Futures Market." Journal of Finance 34 (1979), 895-914.

14. S. F. Richard and M. Sundarasan. "A Continuous Time Equilibrium Model of Forward Prices and Futures Prices in a Multigood Economy." Journal of Financial Economics 9 (1981), 347-72. 